\title{
Hubungan Kausal Penalaran Matematis terhadap Prestasi Belajar Matematika pada Materi Bangun Ruang Sisi Datar ditinjau dari Motivasi Belajar Matematika Siswa
}

\author{
Agus Setiawan \\ IAIM NU Metro Lampung; 490as@gmail.com
}

Submitted : 15-04-2016, Revised : 12-05-2016, Accepted : 16-06-2016

\begin{abstract}
This research is a comparative causal research with factorial design 3 3. The population of this study is all students of class VIII SMP Negeri 1 Simpang Pematang. Sampling was done by cluster random sampling. The sample of this research is students of class VIII B and VIII D. Instruments used to collect data is a test of learning achievement, mathematical reasoning test and student motivation questionnaire. Prior to use for data retrieval, achievement test instruments, reasoning tests and motivational questionnaires were first tested in mathematics. Hypothesis test using two way Anava test with unequal cell. The conclusions of this study are: (1) Students with high mathematical reasoning ability have better learning achievement than students with moderate mathematical reasoning ability, students have better learning achievement than students with low mathematical reasoning, and students with ability High mathematical reasoning has better learning achievement than students with low mathematical reasoning ability, (2) Students with high learning motivation have better learning achievement than students with moderate learning motivation, students with high learning motivation have better learning achievement than Students with low learning motivation, and students with learning motivation are having better learning achievement than students with low learning motivation, (3) There is no interaction between mathematical reasoning ability and motivation of learning mathematics to learning achievement Ar math.
\end{abstract}

Keyword: Achievement; Reasoning; Motivation; Mathematics.

\begin{abstract}
Abstrak
Penelitian ini merupakan penelitian kausal komparatif dengan desain faktorial $3 \times 3$. Populasi penelitian ini adalah seluruh siswa kelas VIII SMP Negeri 1 Simpang Pematang. Pengambilan sampel dilakukan dengan cluster random sampling. Sampel penelitian ini yaitu siswa kelas VIII B dan VIII D. Instrumen yang digunakan untuk mengumpulkan data adalah tes prestasi belajar, tes penalaran matematis dan angket motivasi belajar siswa. Sebelum digunakan untuk pengambilan data, instrumen tes prestasi, tes penalaran dan angket motivasi belajar matematika terlebih dahulu diujicobakan. Uji hipotesis menggunakan uji Anava dua jalan dengan sel tak sama. Kesimpulan penelitian ini adalah: (1) Siswa dengan kemampuan penalaran matematis tinggi mempunyai prestasi belajar yang lebih baik daripada siswa dengan kemampuan penalaran matematis sedang, siswa berkemampuan penalaran matematis sedang mempunyai prestasi belajar yang lebih baik daripada siswa berkemampuan penalaran matematis rendah, dan siswa dengan kemampuan penalaran
\end{abstract}


matematis tinggi mempunyai prestasi belajar yang lebih baik daripada siswa dengan kemampuan penalaran matematis rendah, (2) Siswa dengan motivasi belajar tinggi mempunyai prestasi belajar yang lebih baik daripada siswa dengan motivasi belajar sedang, siswa dengan motivasit belajar tinggi mempunyai prestasi belajar yang lebih baik daripada siswa dengan motivasit belajar rendah, dan siswa dengan motivasi belajar sedang mempunyai prestasi belajar yang lebih baik daripada siswa dengan motivasi belajar rendah, (3) Tidak ada interaksi antara kemampuan penalaran matematis dan motivasi belajar matematika terhadap prestasi belajar matematika.

Kata Kunci: Penalaran; Motivasi; Prestasi; Matematika.

\section{PENDAHULUAN}

Pendidikan merupakan ujung tombak kemajuan bangsa, terutama dalam menghadapi era globalisasi dimana kemajuan teknologi yang pesat menyebabkan perubahan struktur kehidupan dalam masyarakat. Sejalan dengan kemajuan tersebut pendidik dituntut untuk berperan aktif dalam menjalankan misi pendidikan. Berbagai perubahan kurikulum yang dilakukan oleh pemerintah sejak tahun 1975 hingga tahun 2004 yang disempurnakan dengan Kurikulum Tingkat Satuan Pendidikan (KTSP) dan yang terbaru adalah kurikulum 2013 atau yang biasa disebut K13 bertujuan untuk meningkatkan kualitas pendidikan. Akibat adanya perubahan kurikulum ini tidak hanya sekedar menyempurnakan kurikulum sebelumnya tetapi merupakan suatu perombakan baru dalam paradigma pendidikan. Paradigma ini pada prinsipnya menekankan adanya pendidikan yang bermakna bagi siswa. Oleh karena itu guru sangat berperan dalam menentukan proses pembelajaran sehingga pembelajaran yang dilakukan dapat melibatkan kreativitas siswa dalam memahami dan memaknai konsep setiap topik pembelajaran yang dipelajari.

Meskipun guru sekarang berperan menjadi fasilitator akan tetapi guru merupakan salah satu faktor penting yang besar pengaruhnya terhadap proses hasil belajar, bahkan sangat menentukan berhasil tidaknya siswa dalam belajar. Demikian halnya dengan pengembangan K13 menuntut aktivitas dan kreativitas guru dalam membentuk kompetensi siswa. Oleh karena itu, pembelajaran harus sebanyak mungkin melibatkan siswa, agar mereka mampu bereksplorasi untuk membentuk kompetensi dengan menggali kompetensi dan kebenaran secara ilmiah. Dalam kerangka inilah perlunya membangun guru agar mereka menjadi fasilitator dan mitra belajar bagi siswanya. Tugas guru tidak hanya menyampaikan informasi kepada siswanya, tetapi harus menjadi fasilitator yang bertugas memberikan kemudahan belajar kepada seluruh peserta didik, agar mereka dapat termotivasi belajarnya dalam suasana menyenangkan, gembira, penuh semangat, tidak cemas, dan berani mengemukakan pendapat secara terbuka. Dengan kondisi yang demikian dapat diharapkan menghasilkan mutu pendidikan yang berkualitas.

Pada saat sekarang proses pembelajaran matematika tidak seharusnya memposisikan siswa sebagai pendengar ceramah dari guru. Siswa harus diberdayakan agar mau dan mampu berbuat untuk memperkaya pengalaman belajar (learning to do) dengan meningkatkan interaksi dengan lingkungannya baik lingkungan fisik, sosial, maupun budaya, sehingga mampu membangun pemahaman dan pengetahuan konsep matematika terhadap dunia sekitarnya (learning to know). Kesempatan berinteraksi dengan lingkungan dapat 
membangun kesadaran siswa tentang pentingnya pengetahuan dan kepercayaan dirinya (learning to be) dan kesempatan untuk berinteraksi menggali makna dengan berbagai kelompok atau individu yang bervariasi (learning to live together). Jika dalam pembelajaran matematika hanya diberikan rumus dan soal-soal saja, maka pelajaran matematika tetap menjadi kesulitan bagi mereka. Akibatnya mereka tidak senang terhadap pelajaran matematika. Jika siswa tidak senang terhadap pelajaran matematika dapat berakibat prestasinya menjadi rendah. Salah faktor penting dalam keberhasilan pelajaran matematika adalah kemampuan penalaran, karena dalam setiap pemecahan masalah matematika membutuhkan penalaran untuk menyelesaikan masalah matematika tersebut.

Salah satu fakta siswa kurang bermotivasi terhadap matematika sebagai penyebab rendahnya hasil belajar matematika adalah banyaknya materi yang harus diselesaikan oleh guru dalam jangka waktu tertentu. Guru cenderung mengajar hanya dengan tujuan mengejar target kurikulum. Apalagi dengan adanya standart kelulusan secara nasional, guru saling berlomba untuk mengejar target kurikulum. Bahkan banyak yang melakukan bimbingan belajar diluar jam sekolah. Kondisi yang demikian menyebabkan guru kurang memperhatikan metode pembelajaran matematika. Akibatnya proses hasil belajar siswa hanya bersifat sementara. Umumnya guru kurang menyadari bahwa mengajar memiliki sifat yang sangat komplek karena melibatkan aspek pedagogis, psikologis dan didaktis secara bersamaan. Menurut Gane aspek psikologis menunjuk pada kenyataan bahwa siswa yang belajar pada umumnya memiliki taraf perkembangan yang berbeda (Mulyasa, 2002). Salah satu aspek psikologis dalam diri siswa atau faktor internal yang berpengaruh terhadap prestasi belajar adalah motivasi. Menurut Slavin Motivasi adalah salah satu faktor yang mempengaruhi keefektifan kegiatan belajar siswa (Baharuddin, 2008).

Melihat beberapa penelitian tersebut mungkin akan muncul pertanyaan mengapa sesuatu yang telah jelas hasilnya masih harus diteliti lagi. Berikut dasar pemikiran yang menjadi alasan peneliti bermaksud meneliti kembali pengaruh motivasi belajar terhadap prestasi belajar matematika. Dari beberapa penelitian yang peneliti temui terkait motivasi belajar, hampir semua peneliti hanya melihat pengaruh secara umum antara motivasi belajar dengan prestasi belajar matematika melalui penelitian korelasional. Dengan kata lain, beberapa penelitian tersebut hanya sampai pada kesimpulan bahwa motivasi belajar memberikan pengaruh yang positif terhadap prestasi belajar matematika. Pada penelitian ini, peneliti bermaksud memperinci tingkatan-tingkatan motivasi belajar siswa yang kemudian akan dilihat pada tingkat mana yamg memberikan pengaruh paling signifikan. Pada penelitian ini juga akan diteliti secara serempak pengaruh antara motivasit dan kemampuan penalaran matematis terhadap prestasi belajar matematika sekaligus melihat interaksi keduanya terhadap prestasi belajar matematika. Peneliti berhipotesis awal bahwa tidak semua tingkatan motivasi belajar memberikan efek yang sama terhadap prestasi belajarnya. Hal ini dapat dijadikan pustaka bagi guru dalam mendesain kegiatan pembelajaran secara lebih spesifik dengan memperhatikan tingkat kemampuan penalaran matematis dan motivasi belajar siswa. Karena yang selama ini peneliti temui, banyak guru yang merencanakan suatu kegiatan pembelajaran tanpa memperhatikan faktor-faktor yang mempengaruhi prestasi belajar seperti kemampuan penalaran matematis dan motivasi belajar. 
Berdasarkan beberapa hal yang telah diuraikan tersebut, peneliti tertarik melakukan penelitian kausal komparatif dengan melihat secara serempak pengaruh dua variabel terhadap prestasi belajar matematika yakni kemampuan penalaran matematis dan motivasi belajar matematika. Prestasi adalah bukti usaha yang sudah dicapai setelah melakukan sesuatu (Winkel, 1986). Arifin mengemukakan bahwa "Prestasi adalah hasil dari kemampuan, keterampilan, dan sikap seseorang dalam menyelesaikan suatu hal" (Arifin, 1998). "Prestasi belajar adalah penilaian hasil usaha kegiatan belajar yang dinyatakan dalam bentuk simbol, angka, huruf, atau kalimat yang dapat mencerminkan hasil yang sudah dicapai oleh anak dalam periode tertentu". Dari pendapat di atas dapat diambil kesimpulan bahwa yang dimaksud dengan prestasi adalah suatu buah karya atau hasil yang dicapai oleh seseorang yang dinyatakan dengan angka atau huruf, setelah melakukan suatu kegiatan usaha. Prestasi merupakan ukuran dari tingkat kemampuan siswa dalam memahami suatu materi pelajaran melalui suatu proses evaluasi. Di mana prestasi itu nantinya akan mendapatkan penghargaan dari orang lain. Pencapaian suatu prestasi yang gemilang harus diusahakan dengan melakukan kegiatan secara maksimal. Prestasi juga dapat dijadikan sebagai tolak ukur keberhasilan seseorang.

Motivasi belajar adalah merupakan faktor psikis yang bersifat non-intelektual (Sardiman, 2008). Peranannya yang khas adalah dalam hal penumbuhan gairah, merasa senang dan semangat untuk belajar". Dari berbagai pendapat diatas dapat disimpulkan bahwa motivasi belajar matematika adalah dorongan atau keinginan seseorang untuk mencapai suatu keberhasilan atau berprestasi dalam belajar matematika.

Mengenai pengertian penalaran, Keraf menjelaskan bahwa penalaran adalah proses berpikir yang berusaha menghubung-hubungkan fakta-fakta atau evidensi-evidensi yang diketahui menuju suatu kesimpulan (Uno, 2011). Sementara Shadiq mendefinisikan penalaran adalah sebagai suatu kegiatan, suatu proses atau suatu aktivitas berpikir untuk menarik kesimpulan atau membuat suatu pernyataan baru yang benar berdasarkan pada beberapa pernyataan yang kebenarannya telah dibuktikan atau diasumsikan sebelumnya (Shadiq, 2004). Penalaran merupakan suatu proses berpikir dalam menarik suatu kesimpulan yang berupa pengetahuan (Suriasumantri, 1996). Berdasarkan pendapat ketiga ahli tersebut dapat disimpulkan bahwa penalaran adalah suatu proses berpikir dalam menarik suatu kesimpulan yang berupa pengetahuan dari beberapa pernyataan yang kebenarannya telah dibuktikan. Adapun kemampuan penalaran matematis dalam penelitian ini adalah kemampuan berpikir siswa dalam menarik suatu kesimpulan dari beberapa pernyataan terkait objek matematika.

\section{METODE PENELITIAN}

Penelitian ini merupakan penelitian kausal komparatif yang dirancang dengan desain faktorial $3 \times 3$. Populasi dalam penelitian ini adalah seluruh siswa kelas VIII SMP Negeri 1 Simpang Pematang dan sampel diambil dengan teknik cluster random sampling. Penelitian dilakukan di SMP Negeri 1 Simpang Pematang yang masing-masing diambil kelas VIII B sebagai kelas eksperimen dan kelas VIII E sebagai kelas kontrol. Sampel penelitian ini berjumlah siswa yang terdiri dari 50 siswa. Teknik pengumpulan data adalah metode dokumentasi, metode angket, dan metode tes. Instrumen penelitian terdiri atas tes 
penalaran matematis, angket motivasi belajar matematika dan tes prestasi belajar matematika pada materi Bangun ruang sisi datar. Uji coba instrumen angket kreativitas belajar matematika dan tes prestasi belajar matematika dilakukan di kelas VIII A dengan responden 27 siswa. Untuk instrumen tes prestasi belajar, mengacu pada kriteria yaitu validitas isi, daya pembeda ( $D \geq 0,3$ ) (Budiyono, 2011) tingkat kesukaran $(0,3 \leq P \leq 0,7)$ (Sudijono, 2005), dan reliabilitas $\left(r_{11} \geq 0,7\right)$ (Budiyono, 2011) dari 35 butir soal yang diujicobakan diperoleh 25 butir soal yang digunakan sebagai alat pengambil data prestasi belajar matematika siswa. Uji coba angket motivasi belajar matematika, mengacu pada kriteria yaitu validitas isi, konsistensi internal $(D \geq 0,3)$ dan reliabilitas $\left(r_{11} \geq 0,7\right)$, dari 40 butir pernyataan yang diujicobakan diperoleh 30 butir pertanyaan sebagai alat pengambil data motivasi belajar matematika. Uji prasyarat analisis yaitu uji normalitas dengan Lilliefors dan uji homogenitas dengan uji Bartlett. Uji analisis data yang digunakan yaitu analisis variansi dua jalan dengan sel tak sama (Budiyono, Statistika Untuk Penelitian, 2009).

\section{HASIL PENELITIAN DAN PEMBAHASAN}

Sesuai dengan rancangan penelitian yang telah dirumuskan sebelumnya, uji hipotesis untuk penelitian ini menggunakan anava dua jalan dengan sel tak sama. Uji hipotesis dengan anava dua jalan dengan sel tak sama ini dilakukan setelah dipenuhinya persyaratan normalitas populasi dan homogenitas variansi populasi. Rangkuman hasil perhitungan untuk uji ini disajikan dalam tabel di bawah ini. 
Tabel 3. Rangkuman Analisis Variansi Dua Jalan

\begin{tabular}{llllll}
\hline \multicolumn{1}{c}{ Sumber } & \multicolumn{1}{c}{ JK } & Dk & \multicolumn{1}{c}{ RK } & \multicolumn{1}{c}{$\boldsymbol{F}_{\text {obs } s}$} & \multicolumn{1}{c}{$\boldsymbol{F}_{\alpha}$} \\
\hline Kemampuan Penalaran (A) & 1904,7668 & 2 & 952,3834 & $\begin{array}{l}12,544 \\
8\end{array}$ & 3,18 \\
& & & & 51,304 & 3,18 \\
Motivasi Belajar (B) & 7789,9517 & 2 & 3894,9759 & 8 & \\
& & & & 1,9653 & 2,55 \\
Interaksi (AB) & 596,8289 & 4 & 149,2072 & 7 & \\
Galat & 10400,8083 & 137 & 75,9183 & & \\
Total & 20692,3557 & 145 & & & \\
\hline
\end{tabular}

Dari hasil perhitungan $F_{0 b s}$ untuk $H_{O A}, H_{O B}$ dan $H_{O A B}$ yang hasilnya tampak pada tabel di atas diperoleh keputusan uji bahwa $H_{O A}$ ditolak, $H_{O B}$ ditolak dan $H_{O A B}$ diterima. Berdasarkan keputusan uji tersebut diperoleh kesimpulan sebagai berikut.

1) ada perbedaan efek antar kategori kemampuan penalaran matematis terhadap prestasi belajar matematika.

2) ada perbedaan efek antar kategori motivasi belajar terhadap prestasi belajar matematika.

3) tidak ada interaksi antara kemampuan penalaran matematis dan motivasi belajar terhadap prestasi belajar matematika.

Karena $\mathrm{H}_{\mathrm{OA}}$ ditolak dan $\mathrm{H}_{\mathrm{OB}}$ ditolak sedangkan terdapat tiga nilai untuk variabel kemampuan penalaran matematis dan motivasi belajar maka perlu dilakukan uji lanjut pasca anava untuk melihat lebih lanjut manakah dari ketiga tingkatan kemampuan penalaran matematis dan ketiga tingkatan motivasi belajar yang menghasilkan efek yang berbeda. Uji lanjut pasca anava yang dilakukan yakni uji komparasi ganda antar baris dan antar kolom. Metode komparasi ganda yang digunakan adalah metode Scheffe'.

Sebelum dilakukan uji komparasi ganda antar baris, terlebih dahulu dihitung rerata marginal dan rerata masing-masing sel. Hasil perhitungan rerata tersebut disajikan dalam tabel di bawah ini.

Tabel 4. Rerata Marginal dan Masing-Masing Sel

\begin{tabular}{ccccc}
\hline \multirow{2}{*}{ Kemampuan Penalaran } & \multicolumn{3}{c}{ Motivasi } & Rerata \\
\cline { 2 - 4 } & Tinggi & Sedang & Rendah & Marginal \\
\hline Kemampuan Penalaran Tinggi & 78,32 & 65,87 & 57,38 & 67,02 \\
Kemampuan Penalaran sedang & 69,25 & 57,56 & 55,29 & 60,47 \\
Kemampuan Penalaran rendah & 66,23 & 61,11 & 48,00 & 57,25 \\
Rerata Marginal & 70,81 & 61,58 & 54,48 & \\
\hline
\end{tabular}

Selanjutnya, untuk rangkuman hasil komparasi ganda antar baris disajikan dalam Tabel 5 di bawah ini. 
Tabel 5. Rangkuman Komparasi Ganda

\begin{tabular}{ccc}
\hline$H_{0}$ & $F_{\text {obs }}$ & F Tabel \\
\hline$\mu_{1,}=\mu_{2,}$ & 27,342 & $(2)(3,18)=6,36$ \\
$\mu_{2,}=\mu_{2,}$ & 60,027 & $(2)(3,18)=6,36$ \\
$\mu_{1,}=\mu_{2,}$ & 6,368 & $(2)(3,18)=6,36$ \\
\hline
\end{tabular}

Dengan membandingkan $F_{\text {obs }}$ dengan daerah kritis, terlihat bahwa yang mempunyai perbedaan yang signifikan hanya antara $\mu_{1}$ dengan $\mu_{2}$ dan $\mu_{2}$ dengan $\mu_{\mathrm{a}}$. Dengan memperhatikan rerata marginalnya, dapat disimpulkan bahwa:

a) Siswa dengan kemampuan penalaran tinggi mempunyai prestasi belajar yang lebih baik daripada siswa dengan kemampuan kemampuan penalaran sedang,

b) Siswa dengan kemampuan penalaran tinggi mempunyai prestasi belajar yang lebih baik daripada siswa dengan kemampuan kemampuan penalaran rendah dan

c) Siswa berkemampuan penalaran sedang mempunyai prestasi belajar yang lebih baik daripada siswa berkemampuan kemampuan penalaran rendah.

Hasil uji statistik tersebut kemudian digeneralisasi sebagai hasil penelitian ini yakni siswa dengan kemampuan penalaran matematis kategori tinggi mempunyai prestasi belajar yang lebih baik daripada siswa dengan kemampuan penalaran matematis sedang dan rendah, sedangkan siswa dengan tingkat kemampuan penalaran matematis kategori sedang mempunyai prestasi belajar yang sama dengan siswa berkemampuan penalaran matematis rendah pada siswa kelas VIII SMP N 1 Simpang Pematang Tahun Pelajaran 2015/2016.

Selanjutnya, untuk rangkuman komparasi ganda antar kolom disajikan dalam Tabel 6 di bawah ini.

Tabel 6. Rangkuman Komparasi Ganda

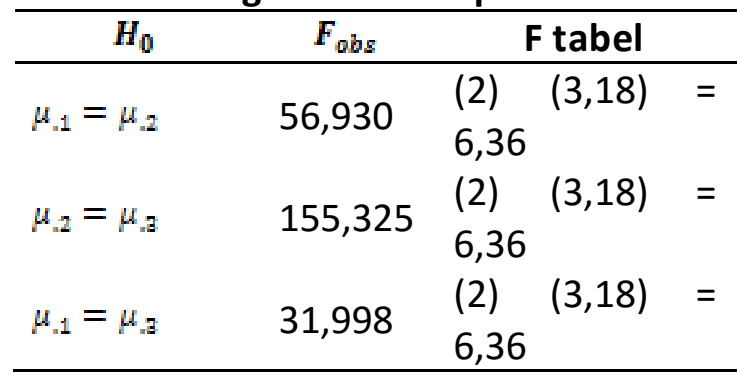

Dengan membandingkan $F_{0 b s}$ dengan daerah kritis, tampak bahwa terdapat perbedaan

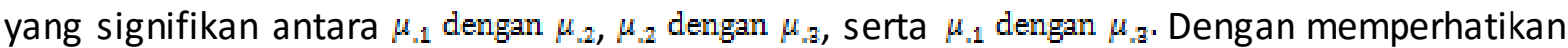
rerata marginal masing-masing kolom, dapat disimpulkan bahwa:

a) Siswa dengan motivasi belajar tinggi mempunyai prestasi belajar yang lebih baik daripada siswa dengan motivasi belajar sedang,

b) siswa dengan motivasi belajar sedang mempunyai prestasi belajar yang lebih baik daripada siswa dengan motivasi belajar rendah,

c) Siswa dengan motivasi belajar tinggi mempunyai prestasi belajar yang lebih baik daripada siswa dengan motivasi belajar rendah. 
Hasil uji statistik tersebut kemudian digeneralisasi sebagai hasil penelitian ini yakni siswa dengan motivasi belajar kategori tinggi mempunyai prestasi belajar yang lebih baik daripada siswa dengan motivasi belajar sedang dan rendah, sementara siswa dengan tingkat motivasi belajar sedang mempunyai prestasi belajar yang lebih baik daripada siswa dengan motivasi belajar rendah pada siswa kelas VIII SMP N 1 Simpang Pematang Tahun Pelajaran 2015/2016.

Hasil ini telah sesuai dengan hipotesis kedua yang dirumuskan dalam penelitian ini. Hal ini memang telah diduga sebelumnya bahwa mempunyai motivasi belajar akan memotivasi siswa untuk belajar giat sehingga akan mempercepat siswa dalam mempelajari dan memahami materi bangun ruang sisi datar.

Selanjutnya, Dari perhitungan dengan anava satu jalan dengan sel tak sama diperoleh $F_{0 b s}$ untuk $H_{O A B}$ sebesar 1,96. Hasil ini memberikan keputusan uji bahwa $\mathrm{H}_{O A B}$ diterima sehingga dapat disimpulkan bahwa tidak ada interaksi antara kemampuan penalaran matematis dan motivasi belajar terhadap prestasi belajar matematika. Karena $\mathrm{H}_{\mathrm{ABB}}$ diterima maka tidak perlu dilakukan uji lanjut pasca anava baik uji komparasi ganda antar sel pada baris yang sama maupun pada kolom yang sama.

Ditinjau dari masing-masing kategori kemampuan penalaran matematis, makna dari tidak ada interaksi antara kemampuan penalaran matematis dan motivasi belajar terhadap prestasi belajar matematika adalah bahwa karakteristik perbedaan antara ketiga kategori kemampuan penalaran matematis untuk setiap kategori motivasi belajar mengacu pada rerata marginal perbedaan ketiga kategori kemampuan penalaran matematis. Secara lebih spesifik dapat dijelaskan bahwa pada masing-masing kategori motivasi belajar, siswa deng an kemampuan penalaran matematis tinggi mempunyai prestasi belajar yang lebih baik daripada siswa dengan kemampuan penalaran matematis sedang, siswa berkemampuan penalaran matematis sedang mempunyai prestasi belajar yang lebih baik daripada siswa berkemampuan penalaran matematis rendah, dan siswa dengan kemampuan penalaran matematis tinggi mempunyai prestasi belajar yang lebih baik daripada siswa dengan kemampuan penalaran matematis rendah.

Selanjutnya, apabila ditinjau dari masing-masing kategori kemampuan matematis, arti dari tidak ada interaksi antara kemampuan penalaran matematis dan motivasi belajar terhadap prestasi belajar matematika adalah bahwa karakteristik perbedaan antar ketiga kategori motivasi belajar untuk setiap kategori kemampuan penalaran matematis sama dengan karakteristik marginal perbedaan ketiga kategori motivasi belajar. Lebih rinci mengenai hal tersebut, dapat dijelaskan bahwa pada masing-masing kategori kemampuan penalaran matematis, siswa dengan motivasi belajar tinggi mempunyai prestasi belajar yang lebih baik daripada siswa dengan motivasi belajar sedang, siswa dengan motivasi belajar tinggi mempunyai prestasi belajar yang lebih baik daripada siswa dengan motivasi belajar rendah, dan siswa dengan motivasi belajar sedang mempunyai prestasi belajar yang lebih baik daripada siswa dengan motivasi belajar rendah. 


\section{SIMPULAN DAN SARAN}

Berdasarkan hasil analisis dan pembahasan terhadap uji hipotesis serta mengacu pada rumusan masalah yang telah dirumuskan pada penelitian ini, diperoleh simpulan sebagai berikut.

1. Siswa dengan kemampuan penalaran matematis tinggi mempunyai prestasi belajar yang lebih baik daripada siswa dengan kemampuan penalaran matematis sedang, siswa berkemampuan penalaran matematis sedang mempunyai prestasi belajar yang sama dengan siswa berkemampuan penalaran matematis rendah, dan siswa dengan kemampuan penalaran matematis tinggi mempunyai prestasi belajar yang lebih baik daripada siswa dengan kemampuan penalaran matematis rendah.

2. Siswa dengan motivasi belajar tinggi mempunyai prestasi belajar yang lebih baik daripada siswa dengan motivasi belajar sedang, siswa dengan motivasi belajar tinggi mempunyai prestasi belajar yang lebih baik daripada siswa dengan motivasi belajar rendah, dan siswa dengan motivasi belajar sedang mempunyai prestasi belajar yang lebih baik daripada siswa dengan motivasi belajar rendah

3. Pada masing-masing kategori motivasi belajar, siswa dengan kemampuan penalaran matematis tinggi mempunyai prestasi belajar yang lebih baik daripada siswa dengan kemampuan penalaran matematis sedang, siswa berkemampuan penalaran matematis sedang mempunyai prestasi belajar yang sama dengan siswa berkemampuan penalaran matematis rendah, dan siswa dengan kemampuan penalaran matematis tinggi mempunyai prestasi belajar yang lebih baik daripada siswa dengan kemampuan penalaran matematis rendah

4. Pada masing-masing kategori kemampuan penalaran matematis, siswa dengan motivasi belajar tinggi mempunyai prestasi belajar yang lebih baik daripada siswa dengan motivasi belajar sedang, siswa dengan motivasi belajar tinggi mempunyai prestasi belajar yang lebih baik daripada siswa dengan motivasi belajar rendah, dan siswa dengan motivasi belajar sedang mempunyai prestasi belajar yang lebih baik daripada siswa dengan motivasi belajar rendah

\section{DAFTAR PUSTAKA}

Arifin, Z. (1998). Evaluasi Instruksional. Bandung: Remaja Karya.

Baharuddin. (2008). Teori Belajar dan Pembelajaran. Jakarta: Ar-Ruzz Media.

Budiyono. (2009). Statistika Untuk Penelitian. Surakarta: UNS Press.

Budiyono. (2011). Penilaian Hasil Belajar. Surakarta: UNS Press.

Mulyasa. (2002). Kurikulum Berbasis Kompetensi. Bandung: Ros dakarya.

Sardiman, A. (2008). Interaksi dan Motivasi Belajar Mengajar. Jakarta: PT Raja Grafindo Persada.

Shadiq, F. (2004). Pemecahan Masalah, Penalaran dan Komunikasi. Yogyakarta: Pusat Pengembangan dan Pemberdayaan Pendidik dan Tenaga Kependidikan Matematika.

Sudijono, A. (2005). Pengantar Evaluasi Pendidikan. Jakarta: Raja Grafindo Persada. 
Suriasumantri, J. (1996). Filsafat Ilmu, Sebuah Pengantar Populer. Jakarta: Pustaka Sinar Harapan.

Uno, H. (2011). Model Pembelajaran. Jakarta: Bumi Aksara.

Winkel, W. (1986). Psikologi Pendidikan dan Evaluasi Belajar. Jakarta: PT Gramedia. 